\title{
LENGTH-WEIGHT RELATIONS OF FISHES (ACTINOPTERYGII) FROM KARST STREAMS IN THE BODOQUENA PLATEAU, WESTERN BRAZIL
}

\author{
Francisco SEVERO-NETO ${ }^{1,2 *}$, Douglas Alves LOPES ${ }^{1}$, Anderson FERREIRA ${ }^{3}$, Bruno Téllez \\ MARTÍNEZ ${ }^{1}$, and Fabio de Oliveira ROQUE ${ }^{1}$ \\ Universidade Federal de Mato Grosso do Sul, Campo Grande, MS, Brazil \\ ${ }^{2}$ Laboratório de Ictiologia, Departamento de Zoologia e Botânica, Instituto de Biociências, Letras e Ciências Exa- \\ tas, Universidade Estadual Paulista "Júlio de Mesquita Filho" (UNESP), São José do Rio Preto, SP, Brazil \\ ${ }^{3}$ Faculdade de Ciências Biológicas, Universidade Federal da Grande Dourados, Dourados, MS, Brazil
}

\begin{abstract}
Severo-Neto F., Lopes D. A., Ferreira A., Martínez B. T., Roque F. O. 2018. Length-weight relations of fishes (Actinopterygii) from karst streams in the Bodoquena Plateau, western Brazil. Acta Ichthyol. Piscat. 48 (4): 419-422.
\end{abstract}

\begin{abstract}
The presently reported study provides the length-weight relations (LWR) for 23 species from headwater streams of the Bodoquena Plateau, which is located on the southern border of the Brazilian Pantanal. The following species were studied Steindachnerina brevipinna (Eigenmann et Eigenmann, 1889); Characidium zebra Eigenmann, 1909; Bryconops melanurus (Bloch, 1794); Aphyocharax dentatus Eigenmann et Kennedy, 1903; Astyanax lacustris Lütken, 1875; Astyanax lineatus (Perugia, 1891); Brachychalcinus retrospina Boulenger, 1892; Creagrutus meridionalis Vari et Harold, 2001; Hemigrammus lunatus Durbin, 1918; Hyphessobrycon eques (Steindachner, 1882); Hyphessobrycon luetkeni (Boulenger, 1887); Jupiaba acanthogaster (Eigenmann, 1911); Moenkhausia bonita Benine, Castro et Sabino, 2004; Odontostilbe pequira (Steindachner, 1882); Piabarchus analis (Eigenmann, 1914); Serrapinus calliurus (Boulenger, 1900); Hoplerythrinus unitaeniatus (Spix et Agassiz, 1829); Hypostomus basilisko Tencatt, Zawadzki et Froelich, 2014; Otocinclus vittatus Regan, 1904; Rineloricaria parva (Boulenger, 1895); Cichlasoma dimerus (Heckel, 1840); Crenicichla lepidota Heckel, 1840; Poecilia reticulata Peters, 1859. Specimens were collected in February and October of 2016. This study represents the first LWR data for 13 species and the maximum standard length for Astyanax lacustris and Moenkhausia bonita.
\end{abstract}

Keywords: Length-weight relation, LWR, Neotropical, fish assemblage, Pantanal, headwaters

\section{INTRODUCTION}

Body size is a key factor determining the metabolism and ecological interactions (Wootton 1998). Moreover, length-weight data are essential for improving the knowledge about growth patterns, condition factors, and biomass of fish species (Le Cren 1951, Froese 2006). Despite the increasing number of reports describing LWR of fish species, data are still lacking for large areas that harbour species-rich communities with high endemism, such as the Upper Paraguay River Basin, in particular, fish fauna that inhabits the headwaters.

The Serra da Bodoquena Plateau is a karst formation located on the southeast of the Pantanal floodplain, Mato Grosso do Sul state, about $200 \mathrm{~km}$ in the northsouth extension and up to $800 \mathrm{~m}$ of altitude above sea level (Sallun Filho et al. 2004). This formation features headwater streams from important drainages of the Upper Paraguay River Basin: Apa in the south and Miranda in the north. In addition to biogeographic aspects, this region is economically important owing to thousands of ecotourists who, each year, are attracted by the transparency of its waters. In fact, this has become the main source of income in Bonito and surrounding towns (Klein et al. 2011). Notwithstanding the important economic aspects of this region, little is known about basic aspects of local fish fauna, especially fish species from small streams, despite recent efforts in the last decade (Casatti et al. 2010, Cordeiro et al. 2013, Severo-Neto et al. 2015, Ferreira et al. 2017). In this context, this work provides information about length-weight relations of 23 fish species from Serra da Bodoquena Plateau, a karstic environment of Pantanal headwaters.

\section{MATERIAL AND METHODS}

The fishes were collected in February and October of 2016 from 25 sample points on eighteen streams of 
the Formoso River sub-basin, Miranda River drainage $\left(20^{\circ} 57^{\prime} \sim 12^{\circ} 12^{\prime} \mathrm{S}, 56^{\circ} 17^{\prime} \sim 56^{\circ} 41^{\prime} \mathrm{W}\right)$. Fishes were captured using a trawl net with $5 \mathrm{~mm}$ mesh, fixed in a $10 \%$ formalin solution for three days, and transferred to $70 \%$ alcohol prior to the measurements. For each specimen, we recorded the standard length (SL) to the nearest 0.01 $\mathrm{cm}$ with a digital calliper. Specimens were weighed to obtain the total weight (TW) to the nearest $0.001 \mathrm{~g}$ with a precision balance. Before the regression analysis, loglog plots of the length-weight pairs were performed to identify outliers, and extreme values were excluded from the analyses (Froese et al. 2011). Length-weight relations were given by linear regression analysis based on the following logarithm

$$
\log (W)=\log (a)+b \times \log (L)
$$

where $W$ is the weight of the fish $(\mathrm{g}), L$ is the standard length ( $\mathrm{mm}), a$ is a scaling constant, and $b$ is a growth parameter (Ricker 1973).

Voucher specimens were deposited at the fish collection of Coleção Zoológica de Referência da Universidade Federal de Mato Grosso do Sul. Identification of the species was based on Britski et al. (2007), Thomas et al. (2013), and Tencatt et al. (2014). Statistical analyses were performed using R software (R core team 2017).

\section{RESULTS}

A total of 1968 individuals, belonging to four orders, 8 families and 23 species, were studied: Steindachnerina brevipinna(Eigenmann etEigenmann, 1889); Characidium zebra Eigenmann, 1909; Bryconops melanurus (Bloch, 1794); Aphyocharax dentatus Eigenmann et Kennedy, 1903; Astyanax lacustris Lütken, 1875; Astyanax lineatus (Perugia, 1891); Brachychalcinus retrospina Boulenger, 1892; Creagrutus meridionalis Vari et Harold, 2001; Hemigrammus lunatus Durbin, 1918; Hyphessobrycon eques (Steindachner, 1882); Hyphessobrycon luetkeni (Boulenger, 1887); Jupiaba acanthogaster (Eigenmann, 1911); Moenkhausia bonita Benine, Castro et Sabino, 2004; Odontostilbe pequira (Steindachner, 1882); Piabarchus analis (Eigenmann, 1914); Serrapinus calliurus (Boulenger, 1900); Hoplerythrinus unitaeniatus (Spix et Agassiz, 1829); Hypostomus basilisko Tencatt, Zawadzki et Froelich, 2014; Otocinclus vittatus Regan, 1904; Rineloricaria parva (Boulenger, 1895); Cichlasoma dimerus (Heckel, 1840); Crenicichla lepidota Heckel, 1840; Poecilia reticulata Peters, 1859 . The coefficient of determination $\left(R^{2}\right)$ ranged from 0.851 to $0.991, a$ values ranged from 0.0037 to 0.0359 , and $b$ values varied between 2.68 and 3.49. All values of $a$ and $b$ fit within the normal range proposed by Froese (2006) of $a$ between 0.001 and 0.05 and $b$ between 2.5 and 3.5. The descriptive statistics and the estimated LWR parameters are summarized in Table 1. Some species were represented by fewer than 30 individuals which is below the recommended number once that above 30 individuals would be the ideal since that may increase the chances of sampling all the length classes in a population and thus avoid a super or underestimation of $b$ (Froese et al. 2011). However, we decided to keep LWR estimates for species with fewer than 30 individuals once they presented high values of $R^{2}$ (Table 1). This study represents the first LWR data for 13 species and the maximum standard length for Astyanax lacustris and Moenkhausia bonita.

\section{DISCUSSION}

This work reports the first LWRs to nine Neotropical species. The allometric coefficients of all species studied ranged from 2.7 to 3.5, as established by Froese (2006). From the 16 species, the LWRs of which are already listed on FishBase, seven had different growth results in our work. Aphyocharax dentatus, Odontostilbe pequira, Piabarchus analis, and Otocinclus vittatus presented positive allometric growth, while Hyphessobrycon luetkeni and Crenicichla lepidota showed negative allometric growth, and Creagrutus meridionalis showed an isometric growth. Variations of $b$ values may be related to population differences, nutritional status, or even the ontogenetic stage of the individuals studied (Froese 2006, Froese et al. 2011). The differences assigned to Astyanax lacustris were possibly related to changes in the taxonomic status of the species, which has been expanded from the former "Astyanax asuncionensis Géry, 1972", harbouring populations of several hydrographic basins, including the Upper Paraguay River (Lucena and Soares 2016). These aspects strengthen the need for further efforts at understanding the growth patterns of a species, especially when species with large geographical distribution are involved.

Serra da Bodoquena streams share the same fate as that of rivers from different freshwater ecoregions which present high endemism and invasion of non-native fish (Daga et al. 2016). In this work, we report the first LWR data to Hypostomus basilisko and Poecilia reticulata. The former species is an armoured catfish species from Serra da Bodoquena and one example of the high endemism in this region, while $P$. reticulata is an exotic species in Brazil introduced through aquarium dumping or the control of mosquitoes. Although its dominance may be indicative of anthropogenic impacts (Cunico et al. 2006), it occurred in small populations in the sites that presented a considerable preserved riparian forest. However, the recent expansion of agriculture in the region may facilitate the populational growth of this species in the future, as a response to the impact and consequent loss of ecological integrity (Ruaro et al. 2018). In view of this, the present work presents preliminary data about fish species from the Formoso Basin and emphasizes the need for further studies to better understand the structure of fish assemblages in this unique region.

\section{ACKNOWLEDGEMENTS}

We thank the Universidade Federal do Mato Grosso do Sul (Campus de Bonito), Instituto Chico Mendes de Conservação da Biodiversidade (ICMBio), and Fundação Neotropica do Brasil for logistical support. This research was supported by PELD Planalto da Bodoquena: redes de interações em longo prazo. 
Table 1

Data from length-weight relations for 23 fish species from the Rio Formoso drainage, western Brazil; the taxonomic order followed Fricke et al. (2018)

\begin{tabular}{|c|c|c|c|c|c|c|c|c|}
\hline Family and species & $n$ & SL range $[\mathrm{cm}]$ & $W$ range $[\mathrm{g}]$ & $a$ & $b$ & $95 \%$ IC of $a$ & $95 \%$ IC of $b$ & $R^{2}$ \\
\hline \multicolumn{9}{|l|}{ Curimatidae } \\
\hline \multicolumn{8}{|l|}{ Crenuchidae } & 0.986 \\
\hline $\begin{array}{l}\text { Characidium zebra } \\
\text { Iguanodectidae }\end{array}$ & 36 & $2.67-5.1$ & $0.200-2.700$ & 0.0098 & 2.88 & $0.0068-0.0141$ & $2.46-3.30$ & 0.879 \\
\hline $\begin{array}{l}\text { Bryconops melanurus } \\
\text { Characidae }\end{array}$ & 32 & $2.8-9.38$ & $0.271-12.880$ & 0.0098 & 3.23 & $0.0077-0.0125$ & $3.11-3.36$ & 0.990 \\
\hline Aphyocharax dentatus & 62 & $2.73-5.4$ & $0.279-2.700$ & 0.0110 & 3.28 & $0.0073-0.0164$ & $2.94-3.62$ & 0.862 \\
\hline Astyanax lacustris ${ }^{\dagger}$ & 174 & $2.75-9.3$ & $0.400-25.340$ & 0.0184 & 3.13 & $0.0160-0.0211$ & $3.05-3.22$ & 0.968 \\
\hline Astyanax lineatus & 538 & $1.61-9.43$ & $0.110-22.710$ & 0.0311 & 2.81 & $0.0287-0.0337$ & $2.76-2.87$ & 0.949 \\
\hline Brachychalcinus retrospina & 10 & $2.49-4.61$ & $0.400-3.200$ & 0.0163 & 3.41 & $0.0113-0.0236$ & $3.14-3.68$ & 0.989 \\
\hline Creagrutus meridionalis & 52 & $2.08-5.10$ & $0.100-2.424$ & 0.0147 & 3.00 & $0.0106-0.0203$ & $2.75-3.25$ & 0.925 \\
\hline Hemigrammus lunatus & 29 & $2.80-3.74$ & $0.400-1.000$ & 0.0108 & 3.49 & $0.0064-0.0183$ & $3.04-3.93$ & 0.902 \\
\hline Hyphessobrycon eques & 43 & $1.99-2.87$ & $0.150-0.530$ & 0.0185 & 3.12 & $0.0134-0.0260$ & $2.74-3.51$ & 0.864 \\
\hline Hyphessobrycon luetkeni & 93 & $2.42-4.81$ & $0.200-2.600$ & 0.0231 & 2.92 & $0.0177-0.0320$ & $2.69-3.15$ & 0.875 \\
\hline Jupiaba acanthogaster & 31 & $2.88-4.33$ & $0.400-1.900$ & 0.0149 & 3.25 & $0.0079-0.0284$ & $2.75-3.74$ & 0.858 \\
\hline Moenkhausia bonita & 172 & $2.10-8.53$ & $0.100-7.700$ & 0.0193 & 2.97 & $0.0158-0.0235$ & $2.81-3.13$ & 0.889 \\
\hline Odontostilbe pequira & 202 & $2.20-3.70$ & $0.100-0.717$ & 0.0117 & 3.24 & $0.0103-0.0132$ & $311-3.38$ & 0.895 \\
\hline Piabarchus analis & 61 & $1.97-3.43$ & $0.097-0.489$ & 0.0112 & 3.17 & $0.0091-0.0137$ & $2.96-3.37$ & 0.947 \\
\hline Serrapinus calliurus ${ }^{\ddagger}$ & 143 & $1.70-3.90$ & $0.100-1.070$ & 0.0187 & 3.10 & $0.0150-0.0234$ & $2.89-3.32$ & 0.851 \\
\hline \multicolumn{9}{|l|}{ Erythrinidae } \\
\hline $\begin{array}{l}\text { Hoplerythrinus unitaeniatus }{ }^{\ddagger} \\
\text { Loricariidae }\end{array}$ & 11 & $4.40-14.82$ & $2.178-68.400$ & 0.0282 & 2.86 & $0.0155-0.0512$ & $2.51-3.20$ & 0.972 \\
\hline Hypostomus basilisko & 27 & $1.90-13.07$ & $0.100-62.840$ & 0.0117 & 3.38 & $0.0093-0.0148$ & $3.25-3.52$ & \\
\hline Otocinclus vittatus & 110 & $2.10-3.19$ & $0.210-0.730$ & 0.0171 & 3.27 & $0.0140-0.0210$ & $3.06-3.49$ & 0.985 \\
\hline Rineloricaria parva & 34 & $2.70-7.44$ & $0.070-2.610$ & 0.0037 & 3.10 & $0.0015-0.0090$ & $2.58-3.62$ & 0.886 \\
\hline \multicolumn{9}{|l|}{ Cichlidae } \\
\hline Cichlasoma dimerus & 23 & $2.40-8.50$ & $0.479-33.340$ & 0.0254 & 3.29 & $0.0211-0.0305$ & $3.11-3.48$ & 0.991 \\
\hline $\begin{array}{l}\text { Crenicichla lepidota } \\
\text { Poecilidae }\end{array}$ & 12 & $1.84-17.06$ & $0.100-31.900$ & 0.0123 & 2.68 & $0.0251-0.0516$ & 2.26 a 3.10 & 0.948 \\
\hline Poecilia reticulata & 49 & $1.50-3.29$ & $0.083-1.030$ & 0.0219 & 3.09 & $0.0189-0.0254$ & $2.92-3.26$ & 0.965 \\
\hline
\end{tabular}

$n=$ number of analysed specimens, $\mathrm{SL}=$ standard length, $W=$ total weight, $a=$ coefficient of proportionality, $b=$ allometric coefficient, IC = confidence limit, $R^{2}=$ coefficient of determination; $\dagger=$ new maximum standard length, $\ddagger=$ no data about LWR in FishBase (Froese and Pauly 2018); Bold indicates contrasting growth based on FishBase data up to May 2018.

\section{REFERENCES}

Britski H.A., Silimon K.Z.S., Lopes B.S. 2007. Peixes do Pantanal: Manual de Identificação. [Fish of the Pantanal: Identification manual.] 2nd edn. Embrapa, Brasília, DF, Brazil. [In Portuguese.]

Casatti L., Romero R.M., Teresa F.B., Sabino J., Langeani F. 2010. Fish community structure along a conservation gradient in Bodoquena Plateau streams, central west of Brazil. Acta Limnologica Brasiliensia 22 (1): 50-59. DOI: 10.4322/actalb.02201007

Cordeiro L.M., Borghezan R., Trajano E. 2013. Distribuição, riqueza e conservação dos peixes troglóbios da Serra da Bodoquena, MS (Teleostei: Siluriformes). [Distribution, richness and conservation of troglobitic fishes from Serra da Bodoquena, MS (Teleostei).] Revista da Biologia 10 (2): 21-27. [In Portuguese with English summary.] DOI: 10.7594/ revbio.10.02.04
Cunico A.M., Agostinho A.A., Latini J.D. 2006. Influência da urbanização sobre as assembleias de peixes em três córregos de Maringá, Paraná. [Influence of urbanization upon fish assemblages in three streams of Maringá, Paraná.] Revista Brasileira de Zoologia 23 (4): 1101-1110. [In Portuguese.] DOI: 10.1590/ S0101-81752006000400018

Daga V.S., Debona T., Abilhoa V., Gubiani É.A., Vitule J.R.S. 2016. Non-native fish invasions of a Neotropical ecoregion with high endemism: A review of the Iguaçu River. Aquatic Invasions 11 (2): 209 223. DOI: 10.3391/ai.2016.11.2.01

Ferreira F.S., Duarte G.S.V., Severo-Neto F., Froehlich O., Súarez Y.R. 2017. Survey of fish species from plateau streams of the Miranda River Basin in the Upper Paraguay River Region, Brazil. Biota Neotropica 17 (3): p. e20170344. DOI: 10.1590/1676-0611-bn-2017-0344 
Fricke R., Eschmeyer W.N., van der Laan R. (eds.) 2018. Catalog of fishes: Genera, species, references. California Academy of Sciences, San Francisco, USA. [Accessed on 10 September 2018.] http://researcharchive.calacademy.org/research/ ichthyology/catalog/fishcatmain.asp

Froese R. 2006. Cube law, condition factor and weightlength relationships: History, meta-analysis and recommendations. Journal of Applied Ichthyology 22 (4): 241-253. DOI: 10.1111/j.1439-0426.2006.00805.x

Froese R., Pauly D. (eds.) 2018. FishBase. [Version 03/2018] http://www.fishbase.org

Froese R., Tsikliras A.C., Stergiou K.I. 2011. Editorial note on weight-length relations of fishes. Acta Ichthyologica et Piscatoria 41 (4): 261-263. DOI: 10.3750/AIP2011.41.4.01

Klein F.M., Escandolhero J.P.O., Lucchese N.R., Mercante M.A., Fávero S., Rodrigues S.C. 2011. Educação ambiental e o ecoturismo na Serra da Bodoquena em Mato Grosso do Sul. [Environmental education and the ecotourism in the serra da bodoquena in mato grosso do sul.] Revista Sociedade e Natureza 23 (2): 311-321. [In Portuguese.]

Le Cren E.D. 1951. The length-weight relationship and seasonal cycle in gonad weight and condition in the perch (Perca fluviatilis). Journal of Animal Ecology 20 (2): 201-219.

Lucena C.A.S., Soares H.G. 2016. Review of species of the Astyanax bimaculatus "caudal peduncle spot" subgroup sensu Garutti et Langeani (Characiformes, Characidae) from the rio La Plata and rio São Francisco drainages and coastal systems of southern Brazil and Uruguay. Zootaxa 4071 (1): 101-125. DOI: 10.11646/ zootaxa.4072.1.5

R Core Team 2017. R: A language and environment for statistical computing. R Foundation for Statistical Computing, Vienna.

Ricker W.E. 1973. Linear regressions in fishery research. Journal of the Fisheries Research Board of Canada 30 (3): 409-434. DOI: 10.1139/f73-072
Ruaro R., Mormul R.P., Gubiani É.A., Piana P.A., Cunico A.M., da Graça W.J. 2018. Non-native fish species are related to the loss of ecological integrity in Neotropical streams: A multimetric approach. Hydrobiologia 817 (1): 413-430. DOI: 10.1007/ s10750-018-3542-y

Sallun Filho W., Karmann I., Boggiani P.C. 2004. Paisagens cársticas da Serra da Bodoquena (MS). [Karstic landscapes of the Serra da Bodoquena (MS).] Pp. 424-433. In: Mantesso Neto V., Bartorelli A., Carneiro C.D.R., Brito Neves B.B. (eds.). Geologia do continente Sul-americano: evolução da obra de Fernando Flávio Marques de Almeida. [Geology of the South American continent: Evolution of the work of Fernando Flávio Marques de Almeida.] (1st edn.) BECA, Campo Grande, Brazil. [In Portuguese.]

Severo-Neto F., Teresa F.B., Froehlich O. 2015. Ecomorphology and diet reflect the spatial segregation between two Siluriformes species inhabiting a stream of the Bodoquena Plateau, in Central Brazil. Iheringia, Série Zoologia 105 (1): 62-68. DOI: 10.1590/16784766201510516268

Tencatt L.F.C., Zawadzki C.H., Froehlich O. 2014. Two new species of the Hypostomus cochliodon group (Siluriformes: Loricariidae) from the rio Paraguay basin, with a redescription of Hypostomus cochliodon Kner, 1854. Neotropical Ichthyology 12 (3): 585-602. DOI: 10.1590/1982-0224-20130162

Thomas M.R., Rodrigues M.S., Cavallaro M.R., Froehlich O., Castro R.M.C. 2013. Loricaria luciae, a new species of whiptail catfish (Siluriformes: Loricariidae) from the Paraguay and lower Paraná River basins of southeastern South America. Zootaxa 3745 (3): 365-378. DOI: 10.11646/zootaxa.3745.3.4

Wootton R.J. 1998. Ecology of teleost fishes. 2 edn. Kluwer Academic Publishers, Fish and Fisheries Series 24, Dordrecht, Boston, London.

Received: 14 June 2018

Accepted: 2 October 2018

Published electronically: 31 December 2018 